\title{
Left Lung, Inferior Lobe, Lateral Basal Segment
}

National Cancer Institute

\section{Source}

National Cancer Institute. Left Lung, Inferior Lobe, Lateral Basal Segment. NCI

Thesaurus. Code C132394.

The lateral basal segment of the inferior lobe of the left lung. 